\title{
Pengembangan Media Pembelajaran Interaktif Contextual Teaching and Learning (CTL) Untuk Siswa Pendidikan Anak Usia Dini (PAUD) di PAUD SAHABAT
}

\section{Bachren Zaini, Mushlihah Purwo Saputri}

\author{
Program Studi Pendidikan Teknik Informatika dan Komputer \\ Universitas Negeri Jakarta \\ Email: bachrenz@unj.ac.id,mushlihah.saputri@yahoo.co.id
}

\begin{abstract}
ABSTRAK
Pendidikan Anak usia dini adalah tahap kehidupan yang menentukan perkembangan anak untuk selanjutnya. tujuan pembelajaran yaitu tercapainya perubahan perilaku pada siswa setelah mengikuti kegiatan pembelajaran. Masalah yang di alami pada saat pembelajaran di PAUD SAHABAT, masih banyak siswa yang belum mengenal huruf, siswa menjadi kesulitan dalam mengeja kata-kata. sehingga anak usia dini tidak dapat mengetahui bentuk huruf, serta mengetahui huruf depan dari sebuah benda, bukan hanya huruf saja, seharusnya anak usia dini juga perlu tahu pengenalan suku kata sampai di rangkai menjadi suatu kata. di PAUD SAHABAT belum adanya pembelajaran berupa benda nyata, karena masih menggunakan metode ceramah hal ini di dapat melalui wawancara guru PAUD SAHABAT, padahal kemampuan mengenal huruf dan mengenal suku kata dalam tahap perkembangan anak usia dini sangat mudah dingat, jika diberi kesempatan untuk beruhubungan langsung dengan benda nyata. Oleh karena itu media sangat di butuhkan sebagai perantara guru ke siswa untuk menyampaikan isi materi tersebut, untuk membantu siswa dapat berfikir secara nyata. Metode pengembangan yang digunakan dalam perancangan media ini menggunakan Research \& Development karena mampu mengatasi kebutuhan nyata melalui pengembangan solusi pada suatu masalah dan dapat menghasilkan produk yang memiliki validitas tinggi karena sudah melalui proses uji validasi oleh tim ahli dan uji coba lapangan.
\end{abstract}

Kata Kunci: Media Pembelajaran, Flash, Media, Contextual Teaching and Learning, Animasi, PAUD, Huruf.

\begin{abstract}
Early childhood education is stage of life that determine a children's development to the next. The goal is to achieve a behavioral changes in students after participating in learning activities. Problems experienced during learning in PAUD SAHABAT, are still many students do not know alphabet yet, so that the students being difficult to spelling words. so that young children can not know the form of letters, as well as knowing the first character of an object, not just the letter alone, early childhood should also need to know the introduction in the chain of syllables to be a word. In PAUD SAHABAT still lack of learning in the form of real objects, because they still use lecture method known through interviews. whereas the ability to recognize letters and familiar syllables in the stage of early childhood development is very easy to be remembered, if given the opportunity to connect directly with real objects. Therefore, the media is needed as an intermediary for the teacher to the students about the content of the material, to help students to be able to think for real. The development method used in the design of this media is the Research \& Development because be able to cope with the real needs through the development of solutions to a problem and can produce products that have high validity because it has been through the process of validation testing by a team of experts and field trials.
\end{abstract}

Keywords: Learning Media, Flash, Media, Contextual Teaching and Learning, Animation, Early Childhood, Alphabet. 


\section{PENDAHULUAN}

Pembelajaran merupakan serangkaian kegiatan komunikasi antara manusia dewasa dengan anak didik secara tatap muka yang bertujuan untuk mewujudkan proses belajar sehingga dapat mengembangkan potensi diri, menambah pengalaman, dan kemampuan anak didik menjadi manusia yang berakal, berkarakter, bermoral, bermartabat, serta menjadi manusia seutuhnya. Keberhasilan pembelajaran sangat dipengaruhi oleh beberapa faktor diantaranya penggunaan media sebagai perantara dalam pembelajaran. Penggunaan media dalam proses penyampaian pengetahuan umum bertujuan untuk memberikan bantuan terhadap perkembangan anak seutuhnya. Namun demikian, masih banyak dijumpai paud yang belum dapat memanfaatkan media pembelajaran khususnya media pembelajaran interaktif.

Berdasarkan observasi yang dilakukan peneliti di PAUD Sahabat, terdapat beberapa kendala yang dialami pada saat pembelajaran berlangsung, diantaranya masih banyak yang belum mengenal huruf yang menyebabkan siswa menjadi kesulitan dalam mengeja kata-kata. Berdasarkan pengamatan peneliti pada studi pendahuluan di lapangan melalui wawancara dengan guru PAUD Sahabat menunjukan bahwa media pembelajaran berupa benda nyata atau pemodelan belum pernah digunakan di PAUD padahal berdasarkan teori bahwa untuk anak usia paud (2-4 tahun) menunjukan tingkat berfikir sensor motorik dan pra operasional konkrit. Dengan kata lain bahwa mereka dapat belajar apabila diberi kesempatan untuk berhubungan langsung dengan benda nyata. Media sangat diperlukan sebagai salah satu perantara antara guru dengan siswa untuk tersampaikannya konsep atau materi.

Berdasarkan permasalahan yang dijumpai di lapangan maka pada penelitian ini akan dikembangkan media pembelajaran berbasis Adobe Flash yang diintegrasikan dengan pembelajaran Contextual Teaching and Learning (CTL). Contextual Teaching and Learning merupakan suatu pendekatan pembelajaran dengan karakteristik memakai sistem pembelajaran yang cocok dengan kinerja otak, untuk menyusun polapola yang mewujudkan makna, dengan cara menghubungkan muatan akademis dengan konteks kehidupan sehari-hari peserta didik. Pentingnya diterapkan model CTL agar informasi yang diterima tidak hanya disimpan dalam memori jangka pendek, yang mudah dilupakan, tetapi dapat disimpan dalam memori jangka panjang sehingga akan dihayati dan diterapkan dalam tugas pekerjaan. Dalam penerapan model pembelajaran contextual teaching and learning (CTL), peneliti menggunakan metode pendekatan montesori yang dimana pendekatan ini dapat mengoptimalkan seluruh kemampuan anak melalui stimulasi dan dipersiapkan.

Pendekatan kontekstual merupakan konsep belajar yang membantu siswa untuk mengaitkan antara materi yang dipelajari dengan situasi dunia nyata siswa dan mendorong siswa membuat hubungan antara pengetahuan yang dimilikinya dengan penerapannya dalam kehidupanya. Model pembelajaran CTL berkaitan dan dapat diimplementasikan dalam pembelajaran dengan metode Tanya Jawab. Dengan demikian anak diberi kesempatan untuk mengaitkan yang mau dipelajari dengan pengetahuan sebelumnya. Selain itu, materi yang akan dipelajari disesuaikan dengan kehidupan nyata yang dialami oleh siswa.

Media hasil pengembangan akan diimplementasikan dalam proses pembelajaran dengan metode Tanya jawab. Metode Tanya Jawab merupakan salah-satu metode pembelajaran dengan cara penyajian pelajaran dalam bentuk pertanyaan yang harus dijawab, terutama dari guru ke siswa, tetapi dapat pula dari siswa ke guru. Metode tanya jawab banyak digunakan di dalam proses pembelajaran.

\section{DASAR TEORI}

\subsection{Belajar}

Belajar merupakan suatu aktivitas mental yang berlangsung dalam interaksi dengan lingkungannya yang menghasilkan perubahan yang bersifat relatif konstan (Baharuddin, 2008: 11). Belajar dimulai sejak manusia lahir sampai akhir hayat. Seseorang dikatakan telah belajar kalau sudah terdapat perubahan tingkah laku dalam dirinya. Belajar memiliki pengertian memperoleh pengetahuan atau menguasai pengetahuan memliki pengalaman, mengingat menguasai pengalaman, dan mendapatkan informasi atau menemukan dengan demikian, belajar memiliki arti dasar adanya kegiatan dan penguasaan tentang sesuatu (Baharuddin dan Wahyuni, 2010: 13).

Menurut Eveline Siregar (2010: 4) yang mengutip dari pernyataan Benyamin S. Bloom, bahwa taksonomi belajar adalah pengelompokan tujuan belajar berdasarkan domain yang terbagi dalam tiga kawasan, yaitu : 1) kawasan kognitif, yaitu perilaku perilaku yang merupakan proses berpikir atau hasil kerja otak; 2) kawasan afektif, yaitu tujuan belajar yang berkenaan dengan minat, sikap dan penyesuaian diri; 3) kawasan psikomotorik, yaitu perilaku yang dihasilkan dari hasil tubuh manusia (Eveline Siregar, 2010: 4).

Belajar adalah suatu proses usaha yang dilakukan seseorang untuk memperoleh suatu perubahan tingkah laku yang baru secara keseluruhan, sebagai hasil pengalaman sendiri dalam interaksi dengan lingkungan (Slameto, 2003: 
2). Belajar adalah suatu proses yang ditandai dengan adanya perubahan pada diri seseorang, perubahan sebagai hasil proses belajar dapat ditunjukkan dalam berbagai bentuk seperti perubahan pengetahuan, pemahaman, sikap dan tingkah laku, keterampilan, kecakapan, kebiasaan serta perubahan aspek-aspek yang ada pada individu yang belajar.

Dapat disimpulkan bahwa belajar merupakan proses usaha manusia dalam memperoleh dan menguasai pengetahuan sehingga nantinya akan terjadi perubahan perilaku dalam kehidupan manusia.

\subsection{Hasil Belajar}

Hasil belajar adalah segala sesuatu yang menjadi milik peserta didik sebagai akibat dari kegiatan belajar yang dilakukannya. Hasil-hasil belajar adalah pola-pola perbuatan, nilai-nilai, pengertian-pengertian, sikap-sikap, apersiasi dan keterampilan (Suprijono, 2009: 5).

Terdapat beberapa unsur dalam proses belajar mengajar adalah rumusan tingkah laku yang di harapkan agar di miliki mahasiswa setelah belajar. Bahan adalah seperangkat pengetahuan ilmiah untuk di sampaikan dalam proses belajar mengajar agar mencapai tujuan yang di tetapkan. Sedangkan penilaian adalah alat untuk mengetahui tingkat keberhasilan proses dan hasil belajar mahasiswa. (Nana Sudjana, 2004: 22).

Kemajuan prestasi belajar mahasiswa tidak saja diukur dari tingkat penguasaan ilmu pengetahuan tetapi juga sikap dan keterampilan. Dengan demikian penilaian hasil belajar mahasiswa mencakup segala hal yang di pelajari, baik itu menyangkut pengetahuan, sikap dan keterampilan. Berdasarkan beberapa penjelasan di atas, maka dapat di simpulkan bahwa hasil belajar adalah segala sesuatu yang dimiliki peserta didik sebagai akibat dari proses pembelajaran dan tes yang telah dilaluinya

\subsection{Pengertian Media dan Media \\ Pembelajaran}

Media adalah manusia, materi atau kejadian yang membangun kondisi yang membuat peserta didik mampu memperoleh pengetahuan keterampilan atau sikap (Arsyad Azhar, 2013: 3). Media merupakan saluran penyampaian pesan dalam komunikasi antar manusia (Nova Firsan, 2009: 204).

Menurut Secara lebih khusus, pengertian media dalam dalam proses belajar mengajar cenderung di artikan sebagai alat-alat grafis, photografis atau elektronis untuk menangkap, memproses dan menyusun kembali informasi visual atau verbal (Sukiman, 2012: 28). Berdasarkan berbagai pengertian di atas, dapat di simpulkan bahwa yang di maksud dengan media pembelajaran adalah segala sesuatu yang dapat digunakan untuk menyalurkan pesan dari pengirim ke penerima sehingga merangsang pikiran, perasaan, perhatian dan minat serta kemauan peserta didik sedemikian rupa sehingga proses belajar terjadi dalam rangka mencapai tujuan pembelajaran secara efektif.

Berdasarkan kamus Teknologi Informasi (2001: 64). interaktif adalah suatu proses interaksi yang saling mempengaruhi antara yang satu dengan yang lainnya. Interaktif dapat membuat seseorang secara yang sadar ataupun tidak menggerakkan semua kemampuan dirinya baik berupa gerakkan tubuh maupun pemikiran melalui otak. interaktif merupakan komunikasi dua arah antara pemakai dengan priferi dan komputer (Warsito, 1997: 431).

Dapat di simpulkan bahwa media interaktif adalah sebuah alat penyampaian informasi yang melibatkan pengguna dengan media. Media interaktif menyediakan sarana penerima input dari penggunanya, Hal tersebut memungkinkan setiap orang yang berbeda untuk mengalami alur yang berbeda pada penggunaan media.

\subsection{Manfaat Media Pembelajaran}

Media pembelajaran mempunyai manfaat yang banyak sekali, antara lain dapat memberikan penjelasan yang lebih konkrit karena materi dapat di sajikan dengan logis dan jelas, baik media pembelajaran berupa gambar, foto, miniatur, film, video, CD interaktif, komputer dan lain sebagainya. Secara umum, media mempunyai kegunaan (Rudi dan Cepi, 2009:9) :

a. Memperjelas pesan agar tidak terlalu verbalistis.

b. Mengatasi keterbatasan ruang, waktu, tenaga dan daya indera.

c. Menimbulkan gairah belajar, interaksi lebih langsung antara murid dengan sumber belajar.

d. Memungkinkan peserta didik belajar mandiri sesuai dengan kemampuan visual, auditori dan kinestetiknya.

e. Memberi rangsangan yang sama, mempersamakan pengalaman dan menimbulkan persepsi yang sama.

\subsection{Langkah-langkah Pengembangan Media Pembelajaran}

Secara garis besar kegiatan pengembangan media pembelajaran terdiri atas tiga langkah besar yang harus di lalui, yaitu kegiatan perencanaan, produksi dan penilaian. Sementara itu dalam rangka melakukan desain atau rancangan pengembangan program media, terdapat urutan langkah-langkah yang harus di ambil dalam pengembangan program media, yaitu di bagi menjadi 6 (enam) langkah sebagai berikut (Arief, dkk., 2011: 64) :
a. Menganalisis kebutuhan dan karakteristik peserta didik
b. Merumuskan tujuan instruksional (instructional objective) dengan operasional khas.
c. Merumuskan butir-butir materi secara terperinci yang mendukung tercapainya tujuan.


d. Mengembangkan alat pengukur keberhasilan.

e. Menulis naskah media.

f. Mengadakan tes dan revisi.

Langkah-langkah dalam melakukan kegiatan pengembangan dan melakukan desain atau rancangan harus dilakukan dengan runtut dan teliti oleh seorang peneliti untuk mengembangkan dan menghasilkan media pembelajaran yang baik sehingga bisa tercapainya tujuan pembelajaran yang diharapkan.

\subsection{Pengertian Flash (Adobe Flash Profesional CS6)}

Perangkat lunak Adobe Flash yang selanjutnya disebut Flash, dulunya bernama "Macromedia Flash", merupakan software multimedia unggulan yang dulunya di kembangkan oleh multimedia, tetapi sekarang di kembangkan dan di distribusikan oleh Adobe System (Andi, 2010: 1). Macromedia dibuat oleh Macromedia Inc, yang merupakan pengembangan dari Macromedia Flash 5 (Iwan, 2010: 234). Pada Flash, semua objek yang akan di animasikan harus sudah berbentuk simbol.

\subsection{Actionscript}

ActionScript atau Panel Action adalah tempat untuk menulis perintah atau script yang dilengkapi oleh berbagai fasilitas dan kecanggihan khusus, Panel ini dibagi lagi dalam beberapa bagian (Zeembry, 2005: 1) :

a. Informasi lokasi, yaitu informasi dimana script diletakkan. Frame, Button dan Movieclip adalah tempat bersemayamnya script-script tersebut. Ketiga tempat tersebut mempunyai sifat dan efek berbeda dalam memperlakukan script.

b. Kategori, yaitu daftar script fungsi yang disusun rapi berdasarkan kategori.

c. Tempat Jelajah, yaitu tempat untuk mengetahui, melihat dan mencari secara cepat dimana script-script diletakkan.

d. Tempat mengetik, yaitu tempat untuk menulis perintah atau script.

ActionScript adalah bahasa pemrograman atau scripting dalam flash yang berfungsi untuk memberi perintah pada flash agar melakukan suatu aksi dalam sebuah rangkaian animasi. Dengan ActionScript dapat membuat animasi atau aplikasi yang mampu berinteraksi langsung dengan pengguna (Budi, 2004: 159).

Dalam suatu interaktivitas, terdapat tiga komponen penting dalam ActionScript yaitu (Hasanuddin dan Fiftin, 2002: 21) :

a. Event (kejadian) : merupakan peristiwa yang terjadi untuk memicu sebuah aksi pada sebuah objek.

b. Action : merupakan aksi atau kerja yang dikenakan atau diberikan pada suatu objek.

c. Target : merupakan objek yang dikenai aksi.

\subsection{Icon}

Sejalan dengan penggunaan simbol-simbol dan tanda-tanda pada kehidupan kita sehari-hari, antar muka pun sering memanfaatkan simbol-simbol dan tanda-tanda ini untuk memberitahu pengguna akan kemampuan dan fasilitas yang di miliki oleh suatu program aplikasi. Ragam dialog yang banyak menggunakan simbol-simbol dan tanda-tanda untuk menunjukan suatu aktifitas tertentu disebut dengan antarmuka berbasis icon (icon-based user interface) (Santosa, 2004: 50). secara teknis, antarmuka berbasis icon boleh dikatakan merupakan variasi dari antarmuka berbasis menu. Icon menunjukan satu aktifitas. Perbedaannya terletak pada cara penyajian pilihan itu. Pada sistem menu, pilihan aktivitas dinyatakan dengan secara tekstual, sementara pada antarmuka berbasis icon, pilihan aktifitas dinyatakan dengan suatu tanda atau simbol yang di sebut pictogram atau icon. Bagaimanapun juga, sesuai dengan pernyataan di atas, icon tetap mempunyai keuntungan visual dibandingkan dengan teks dan karena muatan informasi yang terkandung di dalamnya. Icon jelas-jelas merupakan elemen penting dalam antar muka modern (Santosa, 2004: 50).

\subsection{Animasi}

Animasi merupakan salah satu media pembelajaran yang berbasis komputer yang bertujuan untuk memaksimalkan efek visual dan memberikan interaksi berkelanjutan sehingga pemahaman bahan ajar meningkat. Sebagai media ilmu pengetahuan animasi memiliki kemampuan untuk dapat memaparkan sesuatu yang rumit untuk dijelaskan dengan hanya gambar dan kata-kata saja. Dengan kemampuan ini maka animasi dapat digunakan untuk menjelaskan suatu materi yang secara nyata tidak dapat terlihat oleh mata, dengan cara melakukan visualisasi 'maka materi yang dijelaskan dapat tergambarkan., animasi seperti media-media lain mempunyai peranan yang tersendiri dalam bidang pendidikan khususnya untuk meningkatkan kualitas pengajaran dan pembelajaran (Harun dan Zaidatun, 2004: 6-9).

Berikut merupakan beberapa kepentingan atau kelebihan animasi apabila digunakan dalam bidang pendidikan :

a. Animasi mampu menyampaikan suatu konsep yang kompleks secara visual dan dinamik.

b. Animasi digital mampu menarik perhatian dengan mudah. Animasi mampu menyampaikan suatu pesan dengan lebih baik dibanding penggunaan media yang lain.

c. Animasi digital juga dapat digunakan untuk membantu menyediakan pembelajaran secara maya.

d. Animasi mampu menawarkan satu media pembelajaran yang lebih menyenangkan.

e. Persembahan secara visual dan dinamik yang disediakan oleh teknologi animasi mampu 
memudahkan dalam proses penerapan konsep ataupun demonstrasi.

\subsection{Storyboard}

Storyboard adalah sebuah teknik/metode yang digunakan untuk memvisualisasikan antarmuka (interface) berupa gambar dan teks (Madjadikara, 2005: 49). Gambar-gambar dalam storyboard melukiskan lajur visual dalam script. Sedangkan teks melukiskan kolom atau lajur audio atau sound dalam script. Storyboard mempunyai peranan penting dalam pengembangan multimedia. Storyboard digunakan sebagai alat bantu pada tahapan perancangan multimedia. Proses storyboarding yang dikenal saat ini dikembangkan oleh Waltz Disney Studio sekitar awal tahun 1930.

\subsection{Pendidikan Anak Usia Dini}

Anak usia dini merupakan anak-anak yang berada pada usia yang masih sangat muda, sehingga anak usia dini memerlukan pengasuhan yang serius dari orang tua dan lingkungannya. Anak usia dini adalah manusia yang masih kecil, dapat pula diartikan anak usia dini merupakan anak yang sedang mengalami masa kanak-kanak awal, yaitu anak yang berusia sampai dengan 6 tahun. Usia masa kanak-kanak awal ini merupakan masamasa yang tepat bagi anak-anak untuk sedini mungkin memperoleh pendidikan, supaya pada saat nanti berkemungkinan besar untuk memiliki kecerdasan yang baik. (Musthofa, 2007: 10).

Anak usia dini adalah anak yang berada dalam rentang usia sejak lahir sampai dengan usia 6 tahun. Pada usia ini anak-anak perlu sekali memperoleh perhatian dalam tumbuh kembangnya yang dilakukan melalui pemberian rangsangan pendidikan untuk membantu pertumbuhan dan perkembangan jasmani dan rohani, agar anak memiliki kesiapan dalam memasuki pendidikan lebih lanjut yang diselenggarakan pada jalur formal, non formal dan informal (Hasan, 2009: 15).

Anak usia dini adalah anak usia lahir sampai memasuki pendidikan dasar. Anak usia dini merupakan masa keemasan sekaligus masa kritis dalam tahap kehidupan yang akan menentukan perkembangan anak selanjutnya. Masa ini merupakan masa yang tepat untuk meletakkan dasar-dasar pengembangan maupun fisik, bahasa, sosial-emosional, konsep diri, seni, moral, dan nilai-nilai agama (Mansur, 2005: 18).

Anak usia dini adalah anak yang berada pada rentang usia 0 sampai 6 tahun. Anak usia dini dipandang memiliki karakteristik yang berbeda dengan anak usia di atasnya, sehingga pendidikannya dipandang perlu untuk dikhususkan (Suyanto, 2005: 1).

Berdasarkan pendapat-pendapat tersebut, maka dapat ditegaskan bahwa anak usia dini adalah anak yang berada dalam rentang usia 0-6 tahun. Anak usia dini berada pada masa keemasan yang tepat untuk pemberian rangsangan pendidikan, untuk mengoptimalkan pertumbuhan dan perkembangan anak. Pemberian rangsangan pendidikan perlu memperhatikan karakteristik anak, sehingga potensi anak dapat berkembang dengan optimal.

\section{a. Karakteristik Anak Usia Dini}

Karakteristik anak usia dini merupakan fase pertumbuhan dan perkembangan yang sangat pesat, sehingga memerlukan rangsangan yang tepat dan diberikan secara rutin. Karakteristik anak usia dini akan mengalami perubahan dan perkembangan sesuai usianya. Secara biologis perkembangan anak-anak dapat dibagi menjadi 6 fase perkembangan, mulai dari usia 0 sampai 6 bulan, 7 sampai 12 bulan, 13 sampai 24 bulan, 3 sampai 4 tahun, 5 tahun, dan sampai 8 tahun. Karakteristik anak usia dini, khususnya usia anakanak TK adalah mulai dari usia 4 sampai 6 tahun. Karakteristik perkembangan anak yaitu sudah dapat berkomunikasi dalam berinteraksi, dan mulai belajar mengemukakan pendapat. Anak juga sudah mulai melakukan aktivitas permainan secara bersama-sama, dan mulai mengembangkan keterampilan bahasanya baik secara lisan ataupun tertulis (Partini, 2010: 8-12).

Karakteristik anak memang menarik baik dari sisi perkembangan maupun pencapaian. mengidentifikasi karakteristik anak usia dini menjadi 7 karakter. Karakteristik anak bersifat unik, anak berekspresi relatif spontan, anak bersifat egosentris, memiliki rasa ingin tahu dan antusias yang besar, kaya fantasi, dan merupakan pembelajar yang potensial (Eliyawati, 2005: 2-7).

Karakteristik anak memang berbeda sehingga guru perlu mengetahui karakteristik anak dan dapat menghadapi dengan sikap yang tepat. Karakteristik anak adalah bersifat egosentris, memiliki rasa ingin tahu yang besar, merupakan makhluk sosial, bersifat unik, kaya dengan fantasi, daya konsentrasi yang dimiliki pendek, dan merupakan masa belajar yang paling potensial (Richard dan Hartati, 2005: 8-11).

\section{b. Perkembangan Bahasa Anak Usia Dini}

Perkembangan bahasa anak merupakan perkembangan yang perlu dirangsang sedini mungkin dengan tepat dan diberikan secara teratur. Perkembangan bahasa anak adalah sebagai salah satu dari kemampuan dasar yang harus dimiliki anak-anak, terdiri dari perkembangan bicara, perkembangan menulis, perkembangan membaca, dan perkembangan menyimak (Dhieni, 2007: 31).

Perkembangan bahasa anak merupakan kemampuan anak untuk dapat mengekspresikan segala pikiran dalam bentuk ungkapan. Perkembangan bahasa anak mencakup empat keterampilan. Empat keterampilan bahasa yang dimaksud meliputi keterampilan menyimak, keterampilan berbicara, keterampilan membaca, dan keterampilan menulis (Zubaidah, 2003: 3).

Perkembangan bahasa anak-anak berkembang secara bertahap sehingga memerlukan ketekunan baik dari anak sendiri maupun bagi guru atau 
orang tua dalam memberikan rangsangan. Perkembangan bahasa menjadi 3 tahapan, Tahap perkembangan bahasa antara lain perkembangan bahasa pada masa bayi (0-2 tahun), masa kanakkanak awal (3-6 tahun), dan masa kanak-kanak menengah sampai akhir (7 tahun keatas) (Santrock, 2007: 357-362).

Berdasarkan pendapat di atas disimpulkan bahwa perkembangan bahasa anak memegang peran penting dalam perkembangan anak, khususnya perkembangan kemampuan berbahasa ditaman kanak-kanak, sehingga anak-anak mampu berkomunikasi dengan baik dan dapat mengembangkan potensinya. Perkembangan bahasa anak usia dini khususnya di taman kanakkanak berada pada masa kanak-kanak awal yang terdiri dari kemampuan berbicara, kemampuan membaca, kemampuan menulis, dan kemampuan menyimak. Perkembangan bahasa tersebut membantu anak-anak dalam berbahasa baik secara reseptif maupun secara ekspresif.

\subsection{Kemampuan Mengenal Huruf}

\section{a. Kemampuan Mengenal Huruf Anak Usia} Dini

Kemampuan mengenal huruf adalah tahap perkembangan anak dari belum tahu menjadi tahu tentang keterkaitan bentuk dan bunyi huruf, sehingga anak dapat mengetahui bentuk huruf dan memaknainya (Darjowidjojo, 2003: 300).

Belajar mengenal huruf merupakan komponen hakiki dari perkembangan baca tulis. Anak perlu mngetahui atau mengenal dan memahami huruf abjad untuk akhirnya menjadi pembaca dan penulis yang mandiri dan lancar. Anak- anak yang bisa mengenal dan menyebut huruf-huruf pada daftar abjad dalam belajar membaca memiliki kesulitan lebih sedikit dari anak yang tidak mengenal huruf (Ehri, dkk. Didalam buku Carol Seefeldt, 2008: 330-331).

Sesuai dengan Peraturan Menteri Pendidikan Nasional Republik Indonesia No 58 Tahun 2009 tentang Standar Pendidikan Anak Usia Dini, kemampuan mengenal huruf merupakan bagian dari perkembangan bahasa anak, diantaranya kemampuan mengetahui simbol-simbol huruf dan mengetahui huruf depan dari sebuah benda.

\section{b. Manfaat Mengenal Huruf Anak Usia Dini}

Belajar huruf adalah tonggak kurikulum Taman Kanak-kanak lewat penyingkapan berulang dan bermakna kepada peristiwa-peristiwa baca tulis, sehingga anak menjadi tahu akan huruf-huruf dan mengerti bahwa huruf-huruf membentuk sebuah kata (Seefelt dan Wasik 2008: 375). Strategi pengenalan huruf sejak usia dini sangat bermanfaat bagi perkembangan bahasa anak, karena membantu mempersiapkan anak untuk dapat membaca dengan mudah (Hariyanto, 2009: 82). Anak yang dapat mengenal huruf dengan baik cenderung memiliki kemampuan membaca dengan lebih baik Menurut Bond dan Dykstra (Slamet Suyanto, 2005: 165).

\subsection{Metode Suku Kata}

Metode Depdikbud (1992:92) metode suku kata adalah suatu metode yang memulai pengajaran membaca permulaan dengan menyajikan kata-kata yang sudah di rangkai menjadi suku kata, kemudian suku-suku kata itu di rangkai menjadi kata yang terakhir merangkai kata menjadi kalimat, misalnya:

Mata $\mathrm{Ma}-\mathrm{ta}$

Kaki $\mathrm{Ka}-\mathrm{ki}$

Mata kaki

Metode suku kata adalah suatu metode yang dimulai dengan mengajar suku-suku kata kemudian suku kata digabungkan menjadi kata dan diuraikan menjadi huruf misalnya :

mata Ma - ta m-a-t-a (Amin, 1995: 207).

Setiap metode memiliki keuntungan dan kelemahan masing-masing. Hal ini sesuai dengan yang mengatakan keuntungan dari metode suku kata yang membantu anak dalam membaca permulaan, antara lain (Makmur Karim, 1984: 90) :

a. Dalam membaca tidak ada mengeja huruf demi huruf sehingga mempercepat proses penguasaan kemampuan membaca permulaan.

b. Dapat belajar mengenal huruf dengan mengupas atau menguraikan suku kata yang di pergunakan dalam unsur-unsur hurufnya.

c. Penyajian tidak memakan waktu yang lama.

d. Dapat secara mudah mengetahui berbagai macam kata.

\subsection{Pendekatan Contextual Teaching and Learning (CTL)}

Menurut KBBI (2002:519) Kata kontekstual (Contextual) berasal dari kata context yang berarti hubungan, konteks, suasana dan keadaan (konteks) sehingga Contextual Teaching and Learning (CTL) di artikan sebagai suatu pembelajaran yang berhubungan dengan suasana tertentu. Secara umum contextual mengandung arti : yang berkenan, relevan, ada hubungan atau kaitan langsung, mengikuti konteks; yang membawa maksud, makna, dan kepentingan.

Menurut Depdiknas (2003:5) Contextual Teaching and Learning (CTL) adalah konsep belajar yang membantu guru mengaitkan antara materi yang di ajarkan dengan situasi dunia nyata dan mendorong siswa membuat hubungan antara pengetahuan yang di milikinya dengan perencanaan dalam kehidupan mereka sehari-hari belajar akan lebih mudah bermakna jika anak mengalami apa yang di pelajarinya, bukan mengetahuinya.

Pendekatan kontekstual di singkat menjadi CTL merupakan konsep belajar yang membantu guru mengaitkan antara materi yang di ajarkanya dengan situasi dunia nyata siswa dan mendorong siswa membuat hubungan antara pengetahuan yang di milikinya dengan penerapanya dalam kehidupan mereka sehari-hari (Sagala, 2006: 87-88).

Contextual Teaching and Learning (CTL) atau Pembelajaran Kontekstual terdiri dari 7 komponen, yaitu: (1) Konstruktivisme, (2) Inquiry, (3) 
Questioning, (4) Learning Community, (5) Modeling, (6) Authentic Assesment, (7) Reflection (Sanjaya, 2006: 109-118).

\subsection{Hubungan Media Pembelajaran Dalam Teknologi Pendidikan}

Pemanfaatan sumber belajar merupakan suatu kegiatan memfasilitasi kegiatan belajar yang harus dilakukan oleh setiap pengembang sistem pendidikan. Adapun sumber belajar belajar itu sendiri meliputi semua sumber belajar yang dapat digunakan oleh pelajar baik secara terpisah mapun dalam bentuk gabungan, untuk memberikan fasilitas belajar. (AECT, 1986: 9).

Komponen-komponen sumber belajar adalah bahan dan peralatan. Walapun secara tidak eksplisit media tercantum sebagai komponen sumber belajar, tetapi kedua komponen tersebut sebenarnya adalah komponen media. Alat dan bahan yang kita kenal dengan software dan hardware tidak lain dan tidak bukan adalah media (Sadiman, 1986: 6). Dengan demikian dapat di simpulkan, media merupakan salah satu komponen dalam sumber belajar, dan sekaligus merupakan salah satu bentuk pemecahan belajar menurut teknologi pendidikan dengan melalui suatu perencanaan yang sistematis. Hubungan antara media dengan teknologi pendidikan tidak dapat di lepaskan. Penggunaan media dalam kegiatan pendidikan pembelajaran merupakan bagian dari teknologi pendidikan Jika di gambarkan dalam sebuah skema hubungan antara media pendidikan/pembelajaran dengan teknologi pendidikan akan tampak sebagai berikut (Sukiman, 2012: 25)

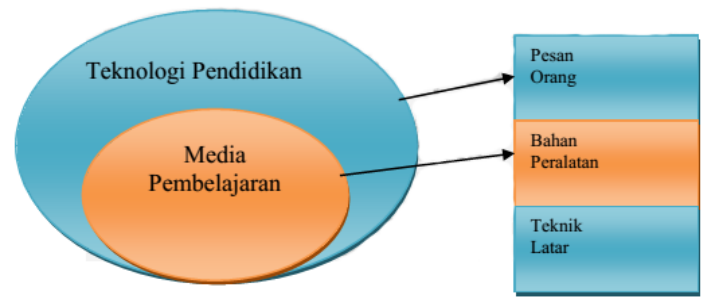

Gambar 1. Hubungan Media Pembelajaran dalam Teknologi Pendidikan (Sukiman, 2012:25)

\section{METODOLOGI}

Luther (Binanto, 2010:259) metodelogi pengembangan Multimedia terdiri dari enam tahap, yaitu concept (pengkonsepan), design (pendesainan), material collecting (pengumpulan materi), assembly (pembuatan), testing (pengujian), dan distribution (pendistribusian). Keenam tahap ini tidak harus berurutan dalam praktiknya, tahaptahap tersebut dapat saling bertukar posisi. Meskipun begitu, tahap concept memang harus menjadi hal yang pertama dikerjakan.

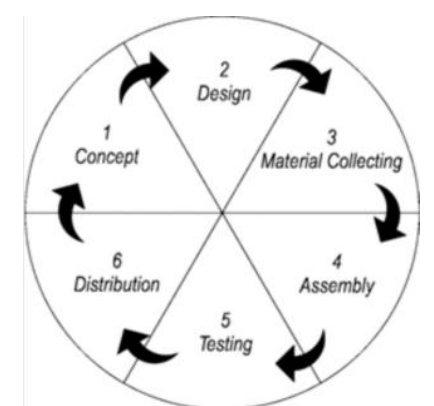

Gambar 1. Tahap Pengembangan Multimedia Development Life Cycle (MDLC)

Penelitian dan pengembangan ini menggunakan metode pengembangan Multimedia Development Life Cycle (MDLC) karna dianggap paling lengkap, fleksibel dan sederhana. Dalam metode ini pengembang melakukan tahap pengujian (testing) untuk mengembangkan produk hasil akhir yang layak digunakan.

\section{a. Kelebihan Multimedia Development Life} Cycle (MDLC)

1. Terstruktur dan berurut secara logis.

2. Dapat digunakan oleh pengembang kecil.

3. Pengujian fleksibel tidak memakan waktu lama.

b. Kekurangan Multimedia Development Life Cycle (MDLC)

1. Seperti halnya waterfall, metode ini idealis sehingga tidak sesuai dengan kenyataan yang ada.

2. Penamaan tahapan dapat membingungkan pengembang karena kurang mencerminkan apa yang dilakukan tahapan tersebut.

3. Bukan metode yang benar-benar baru.

\section{HASIL DAN ANALISIS}

Hasil pengembangan produk adalah tahap hasil dari produk yang sudah diteliti dan dikembangkan. Pada penelitian ini pengembang mengembangkan sebuah media pembelajaran berbasis flash yang berjudul Media Pembelajaran Interaktif Contextual Teaching and Learning (CTL) Untuk Siswa Pendidikan Anak Usia Dini (PAUD). Media ini dikembangkan dengan teknik animasi 2D yang berisikan gambar, logo, typografi serta musik. Pengembangan media ini bertujuan untuk memudahkan siswa paud mempelajari materi pengenalan huruf dan suku kata Penelitian dalam pengembangan produk media ini dilakukan di PAUD Sahabat Calistung dengan obyek penelitian siswa PAUD. Hasil penelitian memberikan hasil sebagai berikut: 


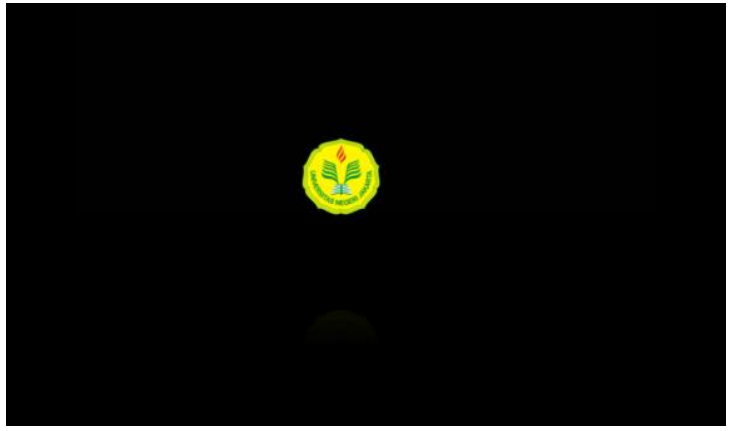

Gambar 1. Tampilan Opening Media

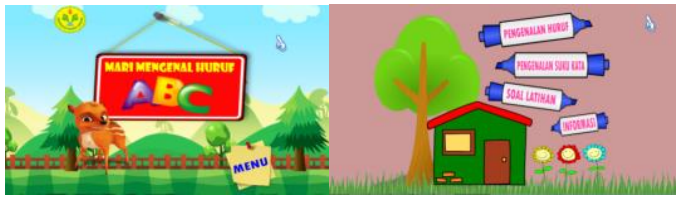

Gambar 2. Tampilan Halaman Utama

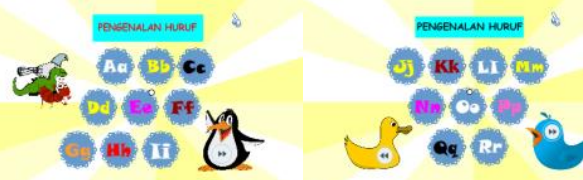

PENGENUAN HuRUF

Ss re op (v)

. $z \mathbf{z}$

Gambar 3. Tampilan Halaman Pengenalan Huruf

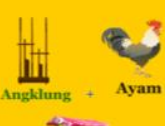

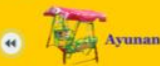

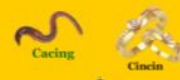

* celama

Gambar 4. Tampilan Halaman Isi Pengenalan Huruf

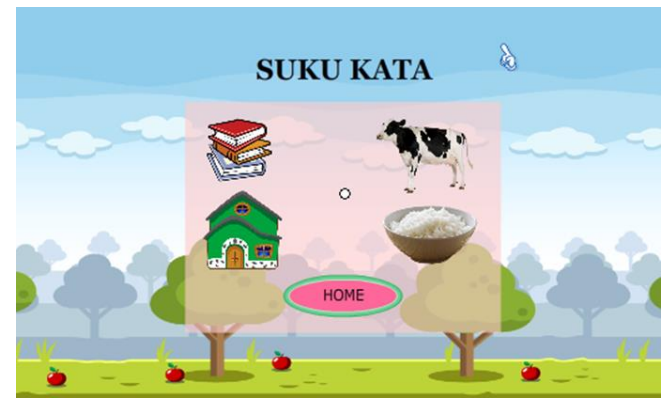

Gambar 5. Tampilan Halaman Suku Kata

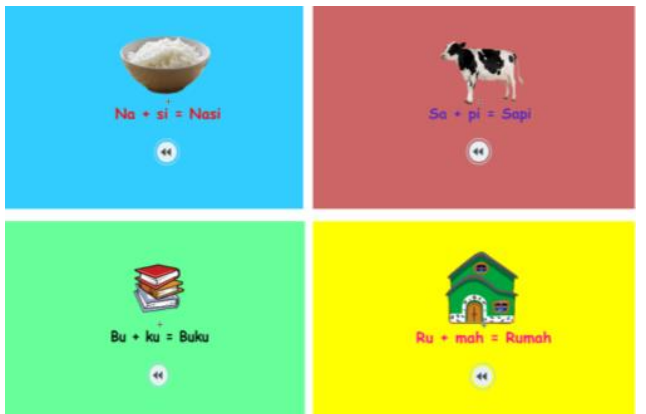

Gambar 6. Tampilan Halaman Materi Suku Kata

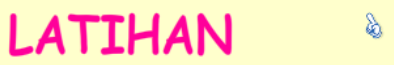

\section{MULAI}

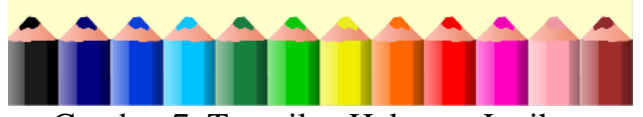

Gambar 7. Tampilan Halaman Latihan

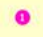

-

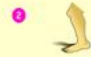

FO-TO BU-KU TI-SU

KA-KI JA-RI KU-KU

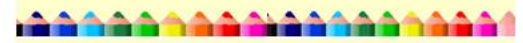

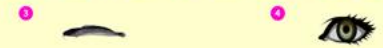

BA-TU TA-LI LE-LE MA-TA DA-GU GI-GL

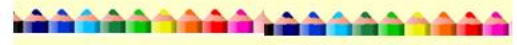
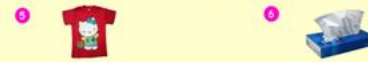

KA-IN BA-JU TO-PL

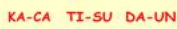

में
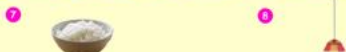

NA-SI PA-DI BE-SI

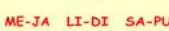

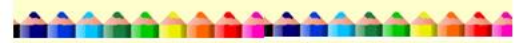

○

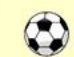

PA-KU PA-LU DA-SI BU-SA BO-LA GU-LA

में

Gambar 8. Tampilan Halaman Isi Soal Latihan

SKOR KAMU
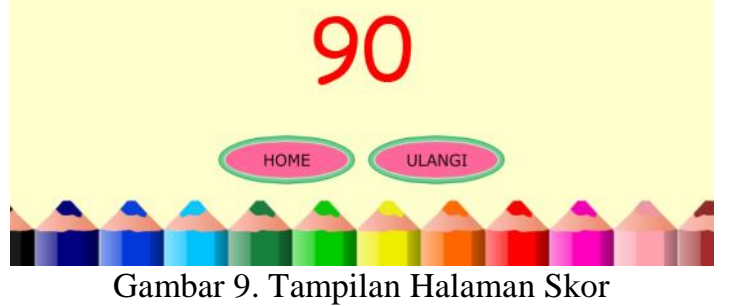

Gambar 9. Tampilan Halaman Skor 


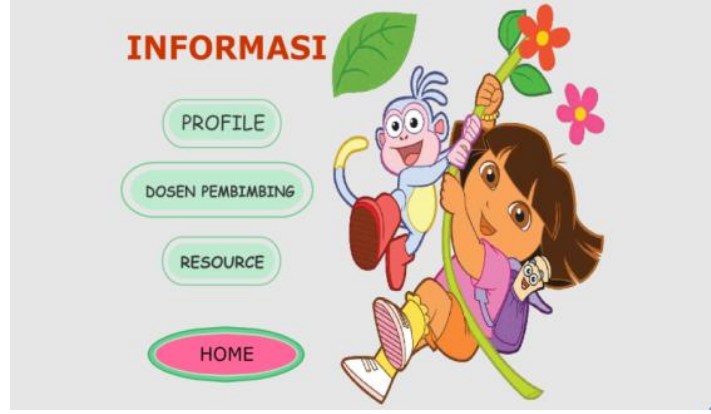

Gambar 10. Tampilan Halaman Informasi

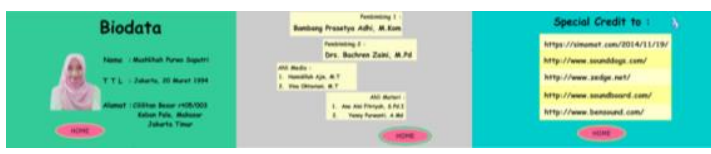

Gambar 11. Tampilan Halaman Informasi

Media pembelajaran yang sudah dibuat diuji kepada ahli materi. Ahli materi disini akan mengevaluasi kelayakan media dari segi kesesuaian data dan informasi yang ditampilkan dalam media tersebut. Instrumen untuk ahli materi menggunakan kuisioner skala likert yang berisikan 17 butir soal.

Setelah dilakukan uji ahli materi maka tahap berikutnya adalah menguji media kepada ahli media. Ahli media disini akan mengevaluasi kelayakan media dari segi kesesuaian pada tampilan media. Instrumen untuk ahli media menggunakan kuisioner skala Likert yang berisikan 20 butir soal.

Pengujian oleh responden merupakan pengujian akhir pada penelitian ini. Pengujian respoden dilakukan sebanyak satu kali, Pengujian terhadap responden ini menggunakan sebuah instrumen yang berisi 15 butir pertanyaan. Berikut tabel hasil pengujian kepada responden:

Tabel 1. Hasil Pengujian Responden

\begin{tabular}{|c|l|c|c|}
\hline $\begin{array}{c}\text { N } \\
\text { o. }\end{array}$ & \multicolumn{1}{|c|}{ Pernyataan } & $\begin{array}{c}\text { Persentase } \\
\text { Kelayakan }\end{array}$ & $\begin{array}{c}\text { Kategori } \\
\text { Kelayakan }\end{array}$ \\
\hline 1 & $\begin{array}{l}\text { Media ini } \\
\text { mudah di } \\
\text { pahami oleh } \\
\text { saya }\end{array}$ & $\mathbf{9 0 , 7 6 \%}$ & $\begin{array}{l}\text { Sangat } \\
\text { Sesuai }\end{array}$ \\
\hline 2 & $\begin{array}{l}\text { Materi yang } \\
\text { disampaikan } \\
\text { mudah dipahami } \\
\text { oleh saya }\end{array}$ & $\mathbf{8 4 , 6 1 \%}$ & $\begin{array}{l}\text { Sangat } \\
\text { Sesuai }\end{array}$ \\
\hline 3 & $\begin{array}{l}\text { Saya dapat } \\
\text { mengeja sebuah } \\
\text { kata }\end{array}$ & $\mathbf{8 3 , 0 7 \%}$ & $\begin{array}{l}\text { Sangat } \\
\text { Sesuai }\end{array}$ \\
\hline 4 & $\begin{array}{l}\text { Saya dapat } \\
\text { memahami } \\
\text { materi sebuah } \\
\text { kata }\end{array}$ & $\mathbf{8 6 , 1 5 \%}$ & $\begin{array}{l}\text { Sangat } \\
\text { Sesuai }\end{array}$ \\
\hline 5 & $\begin{array}{l}\text { Saya } \\
\text { mengetahui }\end{array}$ & $\mathbf{9 0 , 7 6 \%}$ & $\begin{array}{l}\text { Sangat } \\
\text { Sesuai }\end{array}$ \\
\hline
\end{tabular}

\begin{tabular}{|c|c|c|c|}
\hline & $\begin{array}{l}\text { benda/hewan } \\
\text { yang diawali } \\
\text { huruf A-Z }\end{array}$ & & \\
\hline 6 & $\begin{array}{l}\text { Penjelasan } \\
\text { materi mudah } \\
\text { dipahami oleh } \\
\text { saya }\end{array}$ & $89,23 \%$ & $\begin{array}{l}\text { Sangat } \\
\text { Sesuai }\end{array}$ \\
\hline 7 & $\begin{array}{l}\text { Saya senang } \\
\text { belajar } \\
\text { menggunakan } \\
\text { media ini }\end{array}$ & $90,76 \%$ & $\begin{array}{l}\text { Sangat } \\
\text { Sesuai }\end{array}$ \\
\hline 8 & $\begin{array}{l}\text { Saya lebih } \\
\text { mudah } \\
\text { mengenal huruf } \\
\text { dan suku kata } \\
\text { dengan media } \\
\text { ini }\end{array}$ & $84,61 \%$ & $\begin{array}{l}\text { Sangat } \\
\text { Sesuai }\end{array}$ \\
\hline 9 & $\begin{array}{l}\text { Tampilan media } \\
\text { menarik }\end{array}$ & $93,84 \%$ & $\begin{array}{l}\text { Sangat } \\
\text { Sesuai }\end{array}$ \\
\hline 10 & $\begin{array}{l}\text { Saya mendapat } \\
\text { pengetahuan } \\
\text { tentang } \\
\text { pengenalan } \\
\text { huruf dan suku } \\
\text { kata } \\
\text { menggunakan } \\
\text { media ini }\end{array}$ & $95,38 \%$ & $\begin{array}{l}\text { Sangat } \\
\text { Sesuai }\end{array}$ \\
\hline 11 & $\begin{array}{l}\text { Saya dapat } \\
\text { memahami soal } \\
\text { latihan pada } \\
\text { media ini }\end{array}$ & $90,76 \%$ & $\begin{array}{l}\text { Sangat } \\
\text { Sesuai }\end{array}$ \\
\hline 12 & $\begin{array}{l}\text { Saya dapat } \\
\text { mengerjakan } \\
\text { soal latihan } \\
\text { pada media ini }\end{array}$ & $86,15 \%$ & $\begin{array}{l}\text { Sangat } \\
\text { Sesuai }\end{array}$ \\
\hline 13 & $\begin{array}{l}\text { Pengenalan } \\
\text { Huruf ini sesuai } \\
\text { untuk saya }\end{array}$ & $89,23 \%$ & $\begin{array}{l}\text { Sangat } \\
\text { Sesuai }\end{array}$ \\
\hline 14 & $\begin{array}{l}\text { Saya dapat } \\
\text { mendengar } \\
\text { suara dengan } \\
\text { jelas pada media } \\
\text { ini }\end{array}$ & $93,84 \%$ & $\begin{array}{l}\text { Sangat } \\
\text { Sesuai }\end{array}$ \\
\hline 15 & $\begin{array}{l}\text { Audio mudah } \\
\text { dipahami dan } \\
\text { jelas oleh saya }\end{array}$ & $98,46 \%$ & $\begin{array}{l}\text { Sangat } \\
\text { Sesuai }\end{array}$ \\
\hline
\end{tabular}

Hasil penelitian pendahuluan yang dilakukan dengan proses wawancara kepada pihak guru menunjukkan permasalahan bahwa dibutuhkannya media pembelajaran yang memudahkan siswa memahami materi pengenalan huruf dan suku kata. Dengan adanya pengembangan produk media pembelajaran tentang materi pengenalan dan suku kata diharapkan dapat memberikan pembelajaran lebih menarik serta mudah di pahami siswa. Selama proses pengembangan, penelitian, dan implementasi produk media pembelajaran tentang materi pengenalan huruf dan suku kata pada 
pembelajaran siswa PAUD terdapat faktor pendukung dan penghambat, diantaranya:

1. Faktor Pendukung

PAUD yang terbuka dengan perkembangan teknologi sehingga bersedia dibuatkan media untuk pembelajaran.

2. Keterbatasan waktu dalam pengembangan produk sehingga masih ada kekurangan dari produk yang dibuat.

Proses pengembangan produk media informasi visual dilakukan dengan menggunakan metode research and development ( $\mathrm{R} \& \mathrm{D})$ yang secara umum meliputi tahap penelitian awal, pengembangan produk, dan pengujian serta revisi produk. Setelah berhasil mengembangkan produk, maka dilakukan uji fungsional yang hasilnya berfungsi melihat apakah produk sudah sesuai dengan yang diharapkan secara fungsional. Setelah dilakukan uji fungsional, maka selanjutnya dilakukan uji validitas. Uji validitas pertama diuji oleh ahli materi yang hasilnya berfungsi untuk melihat kesesuaian isi materi dari produk. Berdasarkan hasil uji validitas yang dilakukan oleh 4 ahli materi, produk yang dikembangkan mendapat rata-rata nilai sebesar $78,235 \%$ yang artinya termasuk ke dalam kategori baik berdasarkan data interval pada tabel 3.5 dan artinya produk dapat dilanjutkan ke tahap pengujian selanjutnya. Setelah dilakukan uji validitas oleh ahli materi, kemudian dilakukan pengujian oleh ahli media yang hasilnya berfungsi untuk menguji kelayakan serta kesesuaian produk yang dibuat dengan materi yang ingin disampaikan dalam media. Berdasarkan uji validitas yang dilakukan oleh 4 ahli media, produk yang dikembangkan mendapat rata-rata nilai sebesar $79,25 \%$ yang artinya termasuk ke dalam kategori baik berdasarkan data interval pada tabel 3.5 dan artinya produk dapat dilanjutkan ke tahap pengujian selanjutnya. Setelah dilakukan uji validitas oleh ahli media, produk kemudian kembali direvisi Berdasarkan hasil uji validitas yang melibatkan 15 orang responden, produk yang dikembangkan mendapat nilai sebesar 89,84\% yang artinya termasuk ke dalam kategori sangat baik berdasarkan data interval pada tabel 3.5 Berdasarkan hasil pengujian yang telah dilakukan maka, produk dinyatakan telah sesuai untuk digunakan dan siap diproduksi akhir.

\section{KESIMPULAN DAN SARAN}

Kesimpulan yang didapat dari pengembangan dan penelitian produk media pembelajaran di Sahabat Calistung berupa media adalah sebagai berikut :

1. Produk media ini dibuat menggunakan software Adobe Flash Professional CS6.
2. Produk media ini berisikan gambar, grafik, teks, serta musik latar yang bisa membuat menarik dalam penyampaian media pembelajaran.

3. Produk media ini berisikan tentang pengenalan huruf, suku kata, soal latihan dan informasi.

4. Produk media pembelajaran ini berguna untuk membantu siswa-siswi untuk mempelajari materi pengenalan huruf dan suku kata.

5. Produk media pembelajaran sesuai, terintegrasi CTL berhubungan antara materi kehidupan sehari-hari siswa.

6. Produk media ini mendapatkan nilai rata-rata 79,25\% termasuk kategori kelayakan baik saat uji ahli media, 78,235\% termasuk kategori kelayakan baik saat uji 4 ahli materi dan $89,84 \%$ termasuk kategori kelayakan sangat baik saat uji responden.

7. Produk media ini sangat cocok untuk memudahkan guru dalam mengajarkan materi pengenalan huruf dan suku kata.

8. Produk media ini lebih tepat guna untuk anak usia 4-6 tahun karena terdapat kata-kata yang panjang dan terlalu sulit untuk anak usia 2-4 tahun.

Untuk pengembangan selanjutnya, ada beberapa hal yang disarankan oleh penulis antara lain:

1. Media ini hanya berisikan informasi pengenalan huruf, suku kata dan soal latihan diharapkan dapat ditambahkan beberapa soal latihan.

2. Media dibuat lebih menarik dan dengan ditambahkannya seperti gambar yang lebih menarik dan sebagainya.

3. Media bisa dibuat untuk umum, bisa untuk keseluruhan siswa-siswi PAUD.

4. Di dalam media ini dapat diubah menggunakan kata-kata yang lebih dekat dengan kehidupan anak usia 2-4 tahun, dan jangan menggunakan kata bahasa asing.

\section{DAFTAR PUSTAKA}

[1] D AECT. (1986). Definisi Teknologi Pendidikan. Jakarta: PAU-UT dan Rajawali.

[2] Agus, Suprijono. (2009). Cooperative Learning Teori dan Aplikasi PAIKEM. Surabaya: Pustaka Pelajar.

[3] Agus S. Madjadikara. (2005). Bagaimana Biro Iklan Memproduksi Iklan. Jakarta: PT Gramedia Pustaka.

[4] Alwi, Hasan. (2002). Kamus Besar Bahasa Indonesia Edisi Ketiga. Jakarta: Balai Pustaka.

[5] Amin, Moh. (1995). Ortopedagogik Anak Tunagrahita. Bandung: Depdikbud. 
[6] Arif S. Sadiman, dkk. (2011). Media Pendidikan, Pengertian, Pengembangan dan Pemanfaatannya. Jakarta: PT. Raja Grafindo Persada.

[7] Arsyad, Azhar. (2013). Media Pembelajaran. Jakarta: Raja Grafindo Persada.

[8] Baharuddin. (2008). Pendidikan dan Psikologi Perkembangan. Yogyakarta: Ar-Ruzz.

[9] Baharuddin dan Wahyuni. (2010). Teori Belajar dan Pembelajaran. Jogjakarta: ArRuzz Media.

[10] Binanto, Iwan. (2010). Multimedia Digital Interaktif, Teori dan Pengembangannya. Jogja: Andi.

[11] Dardjowidjojo, S. (2003). Psikolingustik Pengantar Pemahaman Bahasa Manusia. Jakarta: Yayasan Obor Indonesia.

[12] Depdikbud. (1992). Pelaksanaan Pengajaran Membaca dan Menulis Permulaan. Jakarta: Depdikbud.

[13] Depdiknas. (2003). Pendekatan Kontekstual, Contextual Teaching and Learning (CTL). Jakarta: Direktorat Pendidikan Dasar dan Menengah Departemen Pendidikan Nasional.

[14] Dhieni, dkk. (2007). Metode Pengembangan Bahasa. Jakarta: Universitas Terbuka.

[15]Eliyawati, Cucu. (2005). Pemilihan dan Pengembangan Sumber Belajar untuk Anak Usia Dini. Jakarta: Depdiknas.

[16] Evelin S. dan Hartini. (2010). Teori Belajar dan Pembelajaran. Bogor: PT Ghalia Indonesia.

[17]Hariyanto, Agus. (2009). Membuat Anak Anda Cepat Pintar Membaca. Yogyakarta: Diva Press.

[18]Harun dan Zaidatun. (2004). Teknologi Multimedia dalam Pendidikan. http://www.ctl.utm.my/publications/manuals/ mm/elemenMM.pdf. Diakses tanggal 12 Mei 2014.

[19] Hasan, Maimunah. (2009). Pendidikan anak usia dini. Jogjakarta: Diva Press.

[20] Hasanuddin dan Fiftin. (2002). Pemrograman Actionscript dengan Flash 5 dan aplikasinya. Yogyakarta: Andi Offset.

[21] Hermawan, Warsito. (1997). Pengantar Metodologi Penelitian. Jakarta: PT. Gramedia Pustaka Umum.

[22] Kamus Teknologi Informasi. (2001). Yogyakarta : Andi.

[23] Karim, Makmur. (1984). Mampu Berbahasa Indonesia. Padang: FPTK Institut Keguruan dan Ilmu Pendidikan.

[24] Kumala, Budi. (2004). Seri Penuntun Praktis Macromedia Flash MX. Jakarta: PT Elex Media Komputindo.

[25] Mansur. (2005). Pendidikan Anak Usia Dini dalam Islam. Yogyakarta: Pustaka Pelajar.
[26] Musthofa, Yasin. (2007). EQ untuk Anak Usia Dini dalam Pendidikan Islam. Jakarta: Seketsa.

[27] Nana Sudjana. (2004). Dasar-Dasar Proses Belajar Mengajar. Bandung: Sinar Baru Algensindo.

[28] Nova, Firsan. (2009). Crisis Public Relations (Bagaimana PR Menangani Krisis Perusahaan). Jakarta: Grasindo.

[29] Partini. (2010). Pengantar Pendidikan Anak Usia Dini. Yogyakarta: Grafindo Litera Media.

[30] Rudi dan Cepi. (2009). Media Pembelajaran: Hakikat Pengembangan, Pemanfaatan dan Penilaian. Bandung: CV Wacana Prima.

[31] Sadiman, Arif. (1986). Media Pendidikan, Pengertian, Pengembangan dan Pemanfaatannya. Jakarta: Rajawali.

[32] Safia, Hartati (2005). Perkembangan Belajar Pada Anak Usia Dini. Jakarta: Depdiknas Ditjen Dikti Pembinaan Pendidikan Tenaga Kependidikan dan Ketenagaan Perguruan Tinggi.

[33] Sagala, S. (2006). Konsep dan Makna Pembelajaran. Bandung: CV. Alfabeta.

[34] Sanjaya, Wina. (2006). Strategi Pembelajaran Berorientasi Standar Proses Pendidikan. Jakarta: Prenada Media Group.

[35] Santosa, I. (2004). Interaksi Manusia dan Komputer. Yogyakata: Andi.

[36] Santrock, J.W. (2007). Perkembangan Anak. Jakarta: Erlangga.

[37] Seefeldt, Carol. (2008). Pendidikan Anak Usia Dini (Alih Bahasa: Pius Nasar). Jakarta: PT. Indeks.

[38] Slameto, 2003. Belajar dan Faktor-Faktor Yang mempengaruhinya. Jakarta: Rineka Cipta.

[39] Sugiyono. (2010). Metode Penelitian Kuantitatif, Kualitatif \& RND. Bandung: Alfabeta.

[40] Sukiman. (2012). Pengembangan Media Pembelajaran. Yogyakarta: Pedajogja.

[41] Sunyoto, Andi. 2010. Adobe Flash + XML=Rich Multimedia Application. Yogyakarta: CV ANDI OFFSET.

[42] Suyanto. (2005). Konsep Dasar Anak Usia Dini. Jakarta: Departemen Pendidikan Nasional.

[43] Suyanto, Slamet. (2005). Dasar-dasar Pendidikan Anak Usia Dini. Yogyakarta: Hikayat Publishing

[44]Zeembry. (2005). 123 Tip \& Trik. Jakarta: PT Elex Media Komputindo

[45]Zubaidah, Eni. (2003). Pengembangan Bahasa Anak Usia Dini. Yogyakarta: FIP UNY 